\title{
Clinical significance of expression levels of serum ADRA1A in hysterocarcinoma patients
}

\author{
LIN PENG $^{1}$, WEI PENG ${ }^{2}$, PENG HU $^{1}$ and HUI-FENG ZHANG ${ }^{1}$ \\ ${ }^{1}$ Department of Gynecologic Oncology, Hubei Cancer Hospital, Wuhan, Hubei 430070; \\ ${ }^{2}$ Department of Radiology, Hubei Cancer Hospital, Wuhan, Hubei 430079, P.R. China \\ Received August 16, 2017; Accepted January 18, 2018
}

DOI: $10.3892 / \mathrm{ol} .2018 .8465$

\begin{abstract}
The clinical significance of the expression level of serum adrenergic receptor $\alpha 1$ (ADRA1A) in hysterocarcinoma patients was determined. Peripheral serum samples were collected at the Hubei Cancer Hospital from 455 patients affected by hysterocarcinoma and 380 healthy adults, who served as the normal control group. We determined the expression levels of ADRA1A by ELISA and analyzed its correlation to clinical features and prognosis of the patients. Compared with the normal control group, the expression of ADRA1A in the average peripheral serum level of hysterocarcinoma patients was clearly increased $(\mathrm{P}<0.05)$. In addition, the expression level of ADRA1A was positively correlated with the FIGO staging for hysterocarcinoma $(r=0.312, \mathrm{P}=0.014)$. Furthermore, the expression levels of serum ADRA1A in patients with metastasis were significantly increased compared to the levels of hysterocarcinoma patients without metastasis $(\mathrm{P}<0.05)$. Our analyses also showed that the expression levels of serum ADRA1A in hysterocarcinoma patients did not correlate with patient factors such as age, tumor invasive depth, tumor size or tumor differentiation degree $(\mathrm{P}>0.05)$. The Kaplan-Meier survival analysis indicated that the median survival time (37.1 months) of patients with a high expression of serum ADRA1A was lower than that of patients with a low expression of serum ADRA1A (68 months) $(\mathrm{P}<0.05)$. The three- and five-year survival rates of patients expressing low serum ADRA1A were, respectively, 74.00 and $62.00 \%$; and the three- and five-year survival rates of patients expressing high levels of serum ADRA1A were 52.00 and $32.00 \%$, respectively, with all the differences being statistically significant $(\mathrm{P}<0.05)$. ADRA1A was highly expressed in the peripheral serum in patients with hysterocarcinoma and the expression of ADRA1A was associated with FIGO staging and lymph node metastasis status. The expression of serum
\end{abstract}

Correspondence to: Dr Hui-Feng Zhang, Department of Gynecologic Oncology, Hubei Cancer Hospital, 116 Zhuodaoquan South Road, Wuhan, Hubei 430070, P.R. China

E-mail: efzi_388634@163.com

Key words: serum ADRA1A, hysterocarcinoma patients
ADRA1A can be used to assess the survival rate and may be involved in the pathogenesis and metastasis progression of hysterocarcinoma.

\section{Introduction}

Hysterocarcinoma is the most common malignant tumor of the female reproductive system and it is the main cause of death for female tumor patients in developing countries (1). The occurrence, proliferation and invasion of the tumor are regulated by many factors and complex signaling pathways (2). Hysterocarcinoma is a common gynecological tumor worldwide. There are approximately 500,000 new cases of hystero carcinoma worldwide every year $(3,4)$. Globally, there are approximately 275,000 patients who succumb to cervical cancer every year (5). Therefore, positive intervention measures for hystero carcinoma are of great significance (6-8). At present, treatments for hysterocarcinoma focus mainly on surgical operation, which is assisted by radio- and chemotherapy, but the prognosis for patients is still not high enough.

Adrenergic receptor $\alpha 1$ (ADRA1A) is located on chromosome 8p (9). Previous findings suggested that adrenergic signals on cell pathways can promote the development of cancer (10-12). However, sufficient evidence on the possible effects of ADRA1A in hysterocarcinoma is still lacking.

This study determined the expression levels of serum ADRA1A in hysterocarcinoma patients in order to analyze their potential clinical significance.

\section{Materials and methods}

Clinical material. In total, 455 patients diagnosed with hysterocarcinoma in the Gynecology and Oncology Department of Hubei Cancer Hospital (Wuhan, China) were selected for the study from May, 2007 to May, 2012. The patients were confirmed with hysterocarcinoma by pathological section biopsies. All the patients were being treated for the first time and had complete clinical and follow-up visit data. Patients who received adjuvant therapy, and those who suffered local recurrences and complications with other tumors were excluded. The patient were aged from 35 to 65 years $(51.6 \pm 2.5$ on average); individuals in the control group were healthy as confirmed by standard health examinations. There were 380 cases in the control group, ranging in age from 37 to 65 years $(52.8 \pm 2.3$ 
Table I. Average expression levels of ADRA1A in peripheral serum of individuals in the two groups.

\begin{tabular}{lcc}
\hline Groups & No. of cases & ADRA1A (pmol/l) \\
\hline Hysterocarcinoma & 455 & $4.164 \pm 1.682$ \\
Healthy control & 380 & $1.243 \pm 0.986$ \\
\hline
\end{tabular}

$\mathrm{P}<0.05$. ADRA1A, adrenergic receptor $\alpha 1$.

on average). General data, such as age or socioeconomic status of the individuals in the two groups showed no statistically significant differences $(\mathrm{P}>0.05)$ ensuring the comparability of the levels of ADRA1A among the groups.

The Ethics Committee of Hubei Cancer Hospital approved this research. All enrolled individuals or their legal guardians signed informed consent forms.

Sample collection. Fasting venous blood $(5 \mathrm{ml})$ from each subject were collected in the morning and placed in coagulation-promoting vacuum tubes. After centrifugation for $20 \mathrm{~min}$ at $8,000 \mathrm{x} \mathrm{g}$, the separated sera were saved at $20^{\circ} \mathrm{C}$. All samples were tested within $24 \mathrm{~h}$.

Testing methods. Serum ADRA1A level was tested using ELISA kits (Shanghai Guangrui Biological Technology, Shanghai, China). All the operations were performed following aseptic operation principles and were conducted according to the manual standards.

Statistical methods. SPSS 20.0 software (IBM Corp., Armonk, NY, USA) was used for data processing. Measurement data were expressed by mean \pm standard deviation. Comparisons were made using the t-test. The Kaplan-Meier survival analysis was used to determine the median survival time of patients. $\mathrm{P}<0.05$ was considered to indicate a statistically significant difference. For correlative analyses, the Spearman's rank correlation was adopted. The numeration correlation coefficient was $r_{s}$.

\section{Results}

Expression of ADRA1A in peripheral serum. Compared with the normal control group, the expression levels of ADRA1A in the peripheral serum of hysterocarcinoma patients were obviously increased $(\mathrm{P}<0.05)$ (Table I).

Correlation between the ADRAIA expression level and the FIGO staging for hysterocarcinoma. The levels of ADRA1A in serum of hysterocarcinoma patients increased gradually with higher FIGO stages (from stages I to IV). However, the average level difference between stages II and I and that between stages IV and III had no statistical difference (P>0.05). Notably, the expression level of ADRA1A was positively correlated with the hysterocarcinoma FIGO staging groups I-II or III-IV ( $\mathrm{r}=0.312, \mathrm{P}=0.014)$ (Table II).

Correlation between the serum ADRAlA level (high or low) in the hysterocarcinoma group and clinicopathological
Table II. Average ADRA1A expression levels in each subgroup of hysterocarcinoma staging in patients.

\begin{tabular}{lcc}
\hline $\begin{array}{l}\text { Hysterocarcinoma } \\
\text { staging }\end{array}$ & $\begin{array}{c}\text { No. of } \\
\text { cases }\end{array}$ & $\begin{array}{c}\text { Average expression levels of } \\
\text { ADRA1A in peripheral serum }\end{array}$ \\
\hline I & 126 & $2.689 \pm 1.568$ \\
II & 150 & $3.455 \pm 1.764$ \\
III & 128 & $4.802 \pm 1.634$ \\
IV & 51 & $5.623 \pm 1.792$ \\
\hline
\end{tabular}

ADRA1A, adrenergic receptor $\alpha 1$.

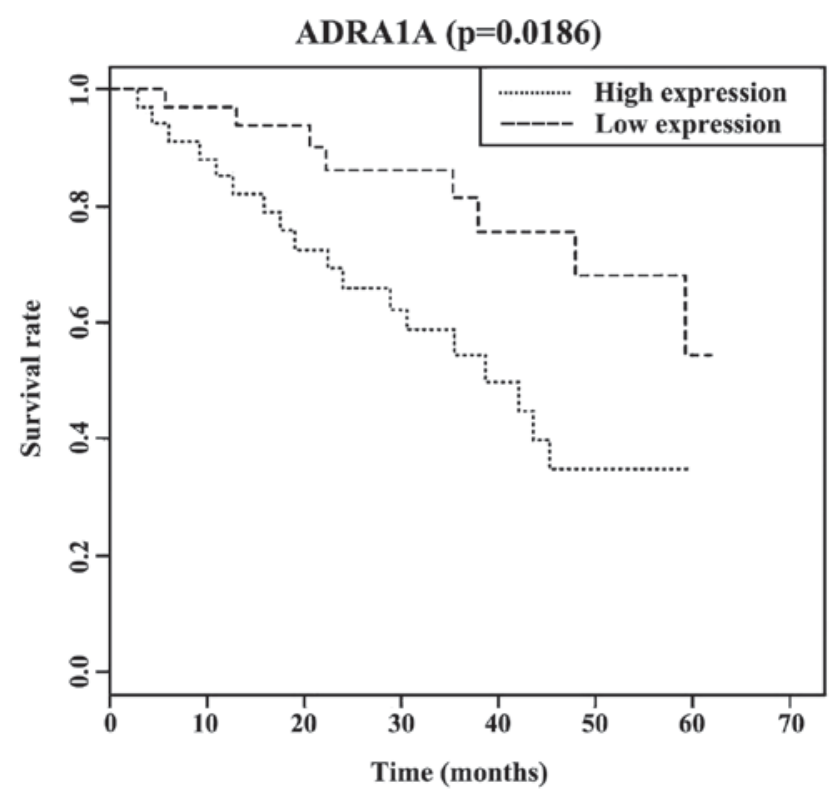

Figure 1. Correlation between the relative expression level of serum ADRA1A and the prognosis of hysterocarcinoma in patients. ADRA1A, adrenergic receptor $\alpha 1$.

characteristics. The 455 hysterocarcinoma patients were divided into two groups, according to their serum ADRA1A expression level. A total of 248 cases had expression levels that were lower than the median expression level (4.16 pmol/l) and were allocated to a low expression group. The remaining 207 cases whose expression level of ADRA1A in serum was higher than the median expression level, were allocated to a high expression group. Thus, within the hysterocarcinoma group, comparison of the relative expression levels of ADRA1A between patients with different FIGO staging classification and pelvic lymph node metastasis revealed differences of statistical significance $(\mathrm{P}<0.05)$. However, a comparison of the relative expression levels between patients with different age, tissue type, lesion size, invasive depth, and differentiation degrees revealed no differences of statistical significance (P>0.05). Finally, a comparison of the expression levels of ADRA1A between patients with different FIGO staging and those with and without lymph node metastasis revealed that patients with lower staging and no metastasis had lower levels than patients with higher staging and presence of metastasis $(\mathrm{P}<0.05)$ (Table III). 
Table III. Correlation between the average serum ADRA1A levels in the hysterocarcinoma group and clinicopathological characteristics.

\begin{tabular}{|c|c|c|c|c|}
\hline Characteristics & $\begin{array}{l}\text { No. of } \\
\text { cases }(n)\end{array}$ & $\begin{array}{l}\text { Low expression level } \\
\text { of serum ADRA1A }\end{array}$ & $\begin{array}{l}\text { High expression level } \\
\text { of serum ADRA1A }\end{array}$ & P-value \\
\hline Age (years) & & & & 0.158 \\
\hline$<50$ & 269 & 140 & 129 & \\
\hline$\geq 50$ & 186 & 108 & 78 & \\
\hline Lesion size $(\mathrm{cm})$ & & & & 0.176 \\
\hline$<4$ & 231 & 98 & 133 & \\
\hline$\geq 4$ & 224 & 150 & 74 & \\
\hline Stage (FIGO) & & & & 0.019 \\
\hline I-II & 276 & 178 & 98 & \\
\hline III-IV & 179 & 29 & 150 & \\
\hline Differentiation degree & & & & 0.201 \\
\hline High & 172 & 70 & 102 & \\
\hline Middle and low & 283 & 178 & 105 & \\
\hline Myometrial invasion depth & & & & 0.191 \\
\hline$<1 / 2$ & 242 & 102 & 140 & \\
\hline$\geq 1 / 2$ & 213 & 146 & 67 & \\
\hline Pelvic lymph node metastasis & & & & 0.031 \\
\hline Yes & 179 & 39 & 140 & \\
\hline No & 276 & 168 & 108 & \\
\hline Tissue type & & & & 0.215 \\
\hline Squamous cell carcinoma & 368 & 176 & 192 & \\
\hline Non-squamous cell carcinoma & 87 & 72 & 15 & \\
\hline
\end{tabular}

ADRA1A, adrenergic receptor $\alpha 1$.

Correlation between the relative expression level of serum $A D R A 1 A$ and the prognosis of hysterocarcinoma patients. The Kaplan-Meier survival analysis indicated that the median survival time (37.1 months) in patients with high expression of serum ADRA1A was lower than that in patients with low expression of serum ADRA1A (68 months), with differences of statistical significance $(\mathrm{P}<0.05)$. Additionally, the three-year and five-year survival rates of patients with low expression of serum ADRA1A were, respectively, 74.00 and $62.00 \%$; and the three- and five-year survival rates of patients with a high expression of serum ADRA1A were, respectively, 52.00 and $32.00 \%$ (Fig. 1).

\section{Discussion}

The ADRAIA gene encodes the $\alpha$-epinephrine receptors (13) for ligands such as epinephrine, catecholamine and norepinephrine. These receptors play important roles in the functioning of the sympathetic nervous system (14). Previous findings have revealed that the expression of ADRA1A receptors can be fine-tuned to regulate the differentiation and apoptosis of epithelial cells $(15,16)$. Additionally, He and Huang suggested that the high expression of ADRA1A exerts a carcinogenetic effect (17). The pathogenesis mechanisms of hysterocarcinoma are dependent on the development of metaplasia of local epithelial cells. The results of the present study suggest that the expression level of serum ADRA1A in patients with hysterocarcinoma is higher than that in healthy individuals, which is in agreement with a published study on the high expression of ADRA1A in prostate cancer (18). We believe the simple testing of ADRA1A in the peripheral blood of hysterocarcinoma patients can be of use as a new reference for hysterocarcinoma screening.

Clinically, the definition of hysterocarcinoma staging usually follows the standard of the International Federation of Gynecology and Obstetrics (FIGO). In this study, it was found that the expression level of ADRA1A was positively correlated with the FIGO staging of hysterocarcinoma $(r=0.312$, $\mathrm{P}=0.014)$. Furthermore, the serum ADRA1A level was closely correlated with the prognosis in patients. High expression levels of serum ADRA1A indicate a poorer prognosis and a significant reduction in the survival rate. A literature review revealed it is possible that the inhibition of adrenergic receptors can inhibit metastasis in liver cancer, which means that the expression level of adrenergic receptors is increased in liver cancer metastasis patients (19). The results of the present study showed that the level of serum ADRA1A in patients with hysterocarcinoma is higher and the total prognosis is poorer, 
which may be related to the fact that the increased expression of ADRA1A somehow promotes tumor metastasis. Moreover, the survival analysis results of the present study showed the three-and five-year survival rates of patients with low expression of serum ADRA1A were respectively 52.00 and $32.00 \%$, and this is basically in agreement with reported results on the survival rate of hysterocarcinoma patients $(20,21)$. On the other hand, the increased serum ADRA1A expression levels predict a poor prognosis for patients. Accordingly, the levels of ADRA1A in serum could be used to predict prognosis in patients.

From the fact that the serum ADRA1A level was positively correlated with the FIGO staging status, it is possible to indirectly associate the correlation between serum ADRA1A level and survival prognosis. However, the conventional FIGO staging adopted in clinical practice does not take into consideration the presence or absence of lymph node metastasis. Accuracy of clinical staging is imperative in treatment guidance and prognosis. Nevertheless, imaging examination for the condition of lymph node metastasis (22) facilitates prognosis evaluation. Therefore, in the present study, we included this variable and also found that patients with lymph node metastasis demonstrated higher serum ADRA1A levels, which obviously occurs in conjunction with a poorer prognosis. Similarly, the serum ADRA1A level seemed to indicate a poor prognosis in cervical cancer (23). We therefore suggest that the determination of serum ADRA1A expression levels should aid doctors in correctly evaluating the hysterocarcinoma staging, lymph node metastasis and prognosis. Nevertheless, limitations of this approach include the lack of data needed to correctly establish standard high and low expression levels of ADRA1A or survival analysis. Consequently, further studies should be carried out to determine these factors.

To conclude, the results of the present study have shown that the serum ADRA1A level is closely correlated with the occurrence and development of hysterocarcinoma. The level can serve as a potential index for the screening for hysterocarcinoma, assist in its diagnosis and serves as a biological index for prognosis evaluation. Testing of serum ADRA1A should therefore be popularized and expanded to include a wider population.

\section{Acknowledgements}

Not applicable.

\section{Funding}

No funding was received.

\section{Availability of data and materials}

The datasets used and/or analyzed during the present study are available from the corresponding author on reasonable request.

\section{Authors' contributions}

LP wrote the manuscript and analyzed blood sample. WP contributed to ELISA. PH and HFZ helped with statistical analysis. All authors read and approved the final manuscript.

\section{Ethics approval and consent to participate}

The Ethics Committee of the Hubei Cancer Hospital (Wuhan, China) approved the present. All enrolled individuals or their legal guardians signed informed consent forms.

\section{Consent for publication}

Not applicable.

\section{Competing interests}

The authors declare that they have no competing interests.

\section{References}

1. Fei R, Chen J and Du P: The expression of miR-574-5p in cervical cancer tissue and its downregulation influence on cervical cancer SiHa cell. Basic Clin Med 35: 458-462, 2015.

2. Berridge MJ, Bootman MD and Roderick HL: Calcium signalling: Dynamics, homeostasis and remodelling. Nat Rev Mol Cell Biol 4: 517-529, 2003.

3. Zong S, Wang X, Yang Y, Wu W, Li H, Ma Y, Lin W, Sun T, Huang Y, Xie Z, et al: The use of cisplatin-loaded mucoadhesive nanofibers for local chemotherapy of cervical cancers in mice. Eur J Pharm Biopharm 93: 127-135, 2015.

4. Shazly SA, Murad MH, Dowdy SC, Gostout BS and Famuyide AO: Robotic radical hysterectomy in early stage cervical cancer: A systematicreview and meta-analysis. Gynecol Oncol: 138, 457-471, 2015. https://doi.org/10.1016/j.ygyno.2015.06.009.

5. Belhadj H, Rasanathan JJ, Denny L and Broutet N: Sexual and reproductive health and HIV services: Integrating HIV/AIDS and cervical cancer prevention and control. Int J Gynaecol Obstet 121 (Suppl 1): S29-S34, 2013.

6. Mabeya H, Khozaim K, Liu T, Orango O, Chumba D, Pisharodi L,Carter J and Cu-Uvin S: Comparison of conventional cervical cytology versus visual inspection with acetic acid among human immunodeficiency virus-infected women in Western Kenya. J Low Genit Tract Dis 16: 92-97, 2012.7.

7. Mwanahamuntu MH, Sahasrabuddhe VV, Pfaendler KS, Mudenda V, Hicks ML, Vermund SH, Stringer JS and Parham GP: Implementation of 'see-and-treat' cervical cancer prevention services linked to HIV care in Zambia. AIDS 23: N1-N5, 2009.

8. Byrd TL, Peterson SK, Chavez R and Heckert A: Cervical cancer screening beliefs among young Hispanic women. Prev Med 38: 192-197, 2004

9. Loo SK, Fisher SE, Francks C, Ogdie MN, MacPhie IL, Yang M, McCracken JT, McGough JJ, Nelson SF, Monaco AP, et al: Genome-wide scan of reading ability in affected sibling pairs with attention-deficit/hyperactivity disorder: Unique and shared genetic effects. Mol Psychiatry 9: 485-493, 2004.

10. Cole SW and Sood AK: Molecular pathways: Beta-adrenergic signaling in cancer. Clin Cancer Res 18: 1201-1206, 2012.

11. Fitzgerald PJ: Beta blockers, norepinephrine, and cancer: An epidemiological viewpoint. Clin Epidemiol 4: 151-156, 2012.

12. Fitzgerald PJ: Is norepinephrine an etiological factor in some types of cancer? Int J Cancer 124: 257-263, 2009.

13. Freitas SR, Pereira AC, Floriano MS, Mill JG and Krieger JE: Association of alphala-adrenergic receptor polymorphism and blood pressure phenotypes in the Brazilian population. BMC Cardiovasc Disord 8: 40, 2008.

14. Liu YR, Loh EW, Lan TH, Chen SF, Yu YH, Chang YH, Huang CJ, Hu TM, Lin KM, Yao YT, et al: ADRA1A gene is associated with BMI in chronic schizophrenia patients exposed to antipsychotics. Pharmacogenomics J 10: 30-39, 2010.

15. Higgins JR and Gosling JA: Studies on the structure and intrinsic innervation of the normal human prostate. Prostate Suppl 2 (S2): 5-16, 1989.

16. Chapple CR, Burt RP, Andersson PO, Greengrass P, Wyllie M and Marshall I: Alpha 1-adrenoceptor subtypes in the human prostate. Br J Urol 74: 585-589, 1994.

17. He L and Huang C: MiR-19b and miR-16 cooperatively signaling target the regulator ADRA1A in Hypertensive heart disease. Biomed Pharmacother 91: 1178-1183, 2017. 
18. Katsogiannou M,El Boustany C, Gackiere F,Delcourt P, Athias A, Mariot P, Dewailly E, Jouy N, Lamaze C, Bidaux G, et al: Caveolae contribute to the apoptosis resistance induced by the $\alpha(1 \mathrm{~A})$-adrenoceptor in androgen-independent prostate cancer cells. PLoS One 4: e7068, 2009.

19. Li J, Yang XM, Wang YH, Feng MX, Liu XJ, Zhang YL, Huang S, Wu Z, Xue F, Qin WX, et al: Monoamine oxidase A suppresses hepatocellular carcinoma metastasis by inhibiting the adrenergic system and its transactivation of EGFR signaling. J Hepatol 60: $1225-1234,2014$

20. Baalbergen A, Ewing-Graham PC, Hop WC, Struijk P and Helmerhorst TJ: Prognostic factors in adenocarcinoma of the uterine cervix. Gynecol Oncol 92: 262-267, 2004.

21. Taheri-Kadkhoda Z, Pettersson N, Björk-Eriksson T, Johansson KA. Superiority of intensity-modulated radiotherapy over three-dimensional conformal radiotherapy combined with brachytherapy in nasopharyngeal carcinoma: a planning study. Br J Radiol 81:397-405, 2008.
22. Irie T, Kigawa J, Minagawa Y,Itamochi H, Sato S, Akeshima R and Terakawa N: Prognosis and clinicopathological characteristics of Ib-IIb adenocarcinoma of the uterine cervix in patients who have had radical hysterectomy. Eur J Surg Oncol 26: 464-467, 2000.

23. Douine M, Roue T, Fior A, Adenis A, Thomas N and Nacher M:Survival of patients with invasive cervical cancer in French Guiana, 2003-2008. Int J Gynaecol Obstet 125: 166-167, 2014.

This work is licensed under a Creative Commons Attribution-NonCommercial-NoDerivatives 4.0 International (CC BY-NC-ND 4.0) License. 